\title{
A Study Of The Relationship Between Stock Market Development And Economic Growth And Development For 1994 To 2003
}

\author{
Carl B. McGowan, Jr., Norfolk State University
}

\begin{abstract}
In this paper, we discuss the relationship between the level of economic development and the size of the stock market relative to the total economic output. We find a positive relationship and statistically significant regression coefficients between gross national income per capita and total stock market capitalization to gross national income for each year from 1994 to 2003 for between seventy-eight and one hundred and two countries. A well developed stock market facilitates capital allocation in an economy which is necessary for economic growth and development and provides the large pools of funds to successful entrepreneurs needed for corporate growth.
\end{abstract}

\section{INTRODUCTION}

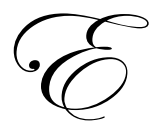

conomic development preceded financial institution development in historical terms. That is, economic development occurred before financial institutions even existed. The first stock market was the Antwerp stock exchange which was founded in 1531. Bills of exchange existed in the $12^{\text {th }}$ century and money lenders likely existed as soon as money began playing a role as a store of value and medium of exchange in economies. Nonetheless, economic development occurred prior to that date, regardless of when the first financial exchange is deemed to have occurred. In fact, economic development occurred before financial intermediaries of any sort existed. However, financial development progressed slowly until the early nineteenth century. Since then, economic development and financial system development have leap-frogged each other. As economic systems become more complex, more complex financial systems are needed as well. Thus, one finds that in some economies, financial system development precedes economic development. In other economies, economic system development precedes financial system development. And, in still other economies, financial system development and economic development are co-integrated. Economic systems do not move in lock-step and each economic system is at a different level of development. As an economic system grows, the growth eventually takes the system beyond the capabilities of the existing financial system. As the economic system slows, the financial system must adapt until new innovations allow the economic system to begin growth again. It is not difficult to imagine a period when both the economic system and the financial system are both growing. ${ }^{1}$ Given that economic systems develop at different rates and are at different stages of development, empirical analysis is complicated. ${ }^{2}$

\section{ECONOMIC DEVELOPMENT}

Diamond (1997) discusses why economic development began and expanded over the last 13,000 years as it did. Diamond argues that food production lead to the economic surpluses that allowed some societies to develop

\footnotetext{
${ }^{1}$ Demirguc-Kunt and Maksimovic (1998) find a positive relationship between stock market activity and the legal system and a firm's ability to grow through the external acquisition of funds.

${ }^{2}$ Bekaert, Harvey, and Lumsdaine (2002) use and event study methodology to mitigate the non-synchronous economic development problem.
} 
and expand while others did not develop and expand. Agriculture arose in the fertile crescent and in Asia because of the abundance of species of plant and animal that could be domesticated. Since few of the total number of plants and animals available are domesticable, having a large number of potentially domesticable species of plant and animal to begin is an advantage. In addition, that axis of Eurasia is east-west, rather than north-south, allowing domesticated species to move more readily.

Agricultural surpluses allowed specialization in society and specialization lead to greater and more rapid economic growth. These agricultural surpluses allowed populations to grow and more complex societies to develop. These complex societies were able to support central government, writing, technological advance, and standing armies. Many of the disease germs resulted from close proximity to animals in early farming societies. Much of the population reduction in the western hemisphere resulted from disease rather than military action. Thus, the dominance of some societies resulted from the agricultural surpluses available to them.

Maddison (2001) analyzes economic growth for roughly 2000 years. Maddison posits three reasons for economic growth over this period: conquest or settlement, international trade and capital movements, and technological and institutional innovation. Conquest and settlement provided natural resources, additional land for population relocation, and new species of plants and animals, to expand the food supply. International trade and capital movement lead to the development of financial institutions, such as banking, accountancy, foreign exchange, and credit markets, that enabled more rapid economic development, particularly in Europe.

During the first millennium, world population grew by one-sixth and per capita income did not grow at all. From 100 to $1820 \mathrm{AD}$, population quadrupled and per capita income increased by fifty percent. Since 1820, world population increased five fold and per capita income increased eight fold. However, the distribution of income is uneven with the ratio of income per capita in the highest country being 19 times the per capita income is the poorest country.

Bernstein (2004) argues that the dramatic increase in economic prosperity that began in approximately 1820 resulted from four factors: secure property rights, scientific rationalism, modern capital markets, and modern communication and transportation. Secure property rights provide incentives to entrepreneurs and protect wealth from arbitrary confiscation. Scientific rationalism provides the framework within which innovation can occur. Capital markets provide the financial resources necessary to entrepreneurs to exploit their ideas. Modern communications and transportation are necessary to allow entrepreneurs to provide goods and services quickly and inexpensively throughout the market. Because all four of these factors became available first in Holland and then in England about 1820, economic growth increased rapidly after that point in time. Maddison (2001) estimates that annualized world GDP growth rate from 0 to 1820 was virtually stagnant with GDP rising from 102.5 to 694.4 billion 1990 dollars. For the period from 1820 to 1998, real economic growth averaged 2.21 percent with GDP rising from 102.5 to 33,726 billion 1990 dollars.

Economic expansion, as measured by increases in real GNI, results from increases in population and/or increases in capital. To increase real GNI per capita, a country must increase the amount of labor, the level of capital and the productivity of either labor or capital. ${ }^{3}$ In addition, increases in the productivity of both labor and capital increase real GNI per capita. If economic output increases in proportion to the increase in population, economic development does not occur. For economic development to occur, output per capita must increase, that is, productivity must increase.

Increases in capital productivity result from technological advances. ${ }^{4}$ Increases in labor productivity result from increases in the quality of the labor force, i. e. increases in human capital. Labor force quality can be increased by numerous methods, such as improved education or health care. ${ }^{5}$ Either of these processes requires investment from either private sources or public sources.

\footnotetext{
${ }^{3}$ See, for example, Robert Solow, "A Contribution to the Theory of Economic Growth," Quarterly Journal of Economics, 70, Number 1, February 1956.

${ }^{4}$ See, for example, Joseph A. Schumpeter, Theory of Economic Development, 1911.

${ }^{5}$ See, for example, Theodore Schultz, "Investment in Human Capital," American Economic Review, March 1961.
} 
Public sources of investment are provided by the government. These government financed investments increase capital productivity, for example, by increasing the infrastructure available in the economy. Labor productivity is increased, for example, by education, health care, sanitation facilities, and health and safety regulation. Public investment is paid for by tax revenues or by borrowing by the government.

Private sources of investment are provided by individuals and corporations. Individuals can increase their stock of human capital through education and on the job training. Corporations provide investment though retaining the earnings of the firm, by borrowing from banks, and by selling securities in capital markets.

\section{STAGE THEORY OF ECONOMIC DEVELOPMENT}

Stage theory of economic development posits that countries move through different stages on the road from being low income economies to being high income economies. Each stage is a prerequisite for the next stage. Rostow (1971) develops a five stage theory of economic development. ${ }^{6}$ Stage one is a traditional society. Most labor is used in subsistence level agriculture with low levels of productivity and savings. Stage two is called the preconditions for take-off. During stage two, economic development begins with the rapid growth in a leading sector of the economy. The leading sector generates surplus output that can be used to create infra-structure needed for rapid economic development. Stage four is the drive to maturity. Rapid growth results in greater surpluses and increased savings with resultant increases in productivity. The population moves from agriculture to urban areas and manufacturing jobs. Stage five is the era of mass consumption. During this stage, economic development becomes self-sustaining. The economy generates significant output that allows for high levels of savings which can be used to increase capital and productivity.

Porter (1990) posits a four stage theory of economic development. ${ }^{7}$ Stage one is factor driven. During this stage, successful companies have an advantage in some factor of production - natural resources, agricultural products, or inexpensive labor. Stage two is investment driven. Successful companies import technology and methods which are used to advantage with local factors of production. By improving the use of the imported technology and methods, companies are able to generate the surplus needed to continue growth and generate the levels of income and savings to continue economic growth. Stage three is innovation driven. As the economy develops and grows, the factors of production cost advantages enjoyed in the investment driven stage disappear as the demand for factors of production increases prices. In stage three, successful firms must innovate to continue to generate the surpluses needed for economic growth. Stage four is the wealth driven economy. In this stage, the economy begins to decline as most advantages enjoyed by companies in earlier stages are lost. The economy loses the competitive edge. This process is not monotonic. Economies can regress from early stages and can even recover from the declining growth and productivity of stage four.

\section{CAPITAL MARKETS}

Capital markets are the primary source of external investment funds for corporations. To provide the function of supplying funds to corporations, markets must be efficient. There are three types of capital market efficiency. Operating efficiency results from having minimal transactions costs. Operating efficiency reduces the cost of trading. Information efficiency results from having markets that react to information quickly. ${ }^{8}$ Information efficiency means that capital markets reflect all information available to investors. And, allocative efficiency results from the process of providing funds to corporations that provide the highest rates of return in the economy. Allocative efficiency means that more productive firms will be able to acquire capital at lower costs than less productive firms. Thus, capital markets both supply the investment funds needed by corporations and direct funds to the corporations that use the funds the most efficiently.

\footnotetext{
${ }^{6}$ Rostow, Walt Whitman. The Stages of Economic Development, Second Edition, Cambridge University Press, Cambridge, 1971.

${ }^{7}$ Porter, Michael E. The Competitive Advantage of Nations, The Free Press, New York, 1990.

${ }^{8}$ Eugene Fama, "Efficient Capital Markets: A Review of Theory and Empirical Work," The Journal of Finance, May 1970, pp. 383-417 defines three forms of stock market information efficiency: weak form, semi-strong, and strong.
} 
How capital markets fulfill these functions is relatively well described in financial economic literature. Markowitz (1952) describes the process that defines a set of portfolios such that each portfolio has the highest possible return for that level of risk or the lowest possible risk for that level of return. ${ }^{9}$ This locus of points is called the efficient frontier. When the efficient frontier is combined with the utility preference function for an investor, the optimal portfolio for that investor is determined. Tobin (1958) extends portfolio theory to the inclusion of a riskfree asset. ${ }^{10}$ The inclusion of the risk-free asset allows the investor to separate the investment decision from the financing decision. Every investor constructs a portfolio composed of two assets - the risk-free asset and a market portfolio which is composed of a market value weighted portfolio of all assets available for investment in the market. Arrow (1964) develops the state preference model to determine the optimal portfolio for an investor in a world with state contingent outcomes and budget constraints, i. e. uncertain outcomes and limited wealth to invest. ${ }^{11}$ Sharpe (1961) develops an asset pricing model for securities based on market risk only. ${ }^{12}$ The Capital Asset Pricing Model, CAPM, greatly simplifies the computations necessary to determine the expected return and risk of a portfolio.

Efficient capital markets allow investors to buy properly priced assets in firms which are more productive, offering higher returns, and allow firms to acquire capital at cost commensurate with the riskiness of those firms. Thus, one might assume that economies that are more developed will have capital markets that are more developed as well. Using data for the time period from 1920 to 1996 for thirty-one countries, ${ }^{13}$ Bernstein (2002) finds a strong relationship between population growth and stock market returns. Stock market growth reflects economic growth.

\section{LITERATURE REVIEW}

Although empirical tests of the relationship between financial development and economic development are not consistent, the bulk of the evidence supports a relationship between financial development and economic development. Demetriades and Hussein (1996) find evidence of both bi-directionality and reverse causality. That is, using units root tests, co-integration tests, and vector auto-regression tests of causality, Demetriades and Hussein find financial development causes economic growth, economic growth causes financial system development, and in some cases, the causality is in both directions. As independent variables, D\&H use the ratio of bank deposit liabilities to nominal GDP and the ratio of bank claims on the private sector to nominal GDP. The dependent variable is real GDP per capita in local currency terms.

Rajan and Zingales (1998) predict the average annual real growth of value added in an industry in the United Stated over the period from 1980-90. As predictor variables R\&Z use the proportion of investments funded with external financing and the ratio of capital spending to net property, plant, and equipment. Industries are further divided into young and old companies. This process allows $R \& Z$ to differentiate industries that are more or less dependent on external financing. $R \& Z$ want to test if financially dependent industries perform better in countries that have more developed financial sectors. As measures of financial development in each of forty-one countries, $R \& Z$ use the ratio of domestic credit plus stock market capitalization to GDP, the ratio of domestic credit to the private sector relative to GDP, and an index of accounting transparency. R\&Z find that financial development facilitates economic development by providing cheaper funds to growing industries.

Levine and Zervos (1998) use measures of stock market liquidity (turnover of shares and value), size (market capitalization), volatility (twelve month rolling standard deviation), integration with world markets (CAPM and APT intercept terms), and bank credit (bank credit to the private sector to GDP) as predictors of economic growth, capital accumulation, improvement in productivity, and savings growth rates for forty-seven countries from

\footnotetext{
${ }^{9}$ Harry Markowitz, "Portfolio Selection," The Journal of Finance, March 1952, pp. 77-91.

${ }^{10}$ James Tobin, "Liquidity Preference as Behavior Towards Risk," The Review of Economic Studies, February 1958, pp. 65-86.

${ }^{11}$ Kenneth Arrow, "The Role of Securities in the Optimal Allocation of Risk Bearing," Review of Economic Studies, 1964, pp. 91-96.

${ }^{12}$ William F. Sharpe, “A Simplified Model for Portfolio Analysis,” Management Science, January 1963, pp. 277-293 and William R. Sharpe, "Capital Asset Prices: A Theory of Market Equilibrium under Conditions of Risk," The Journal of Finance, September 1964, pp. 425-552.

${ }^{13}$ Some countries only had data available for shorter time periods such as Pakistan and Brazil form 1960 to 1996.
} 
1976-93. The authors find a positive relationship between stock market and bank development and economic growth, capital accumulation, and productivity growth. The authors conclude that stock markets provide an easy means to trade the ownership of productive assets which facilitates resource allocation which, in turn, facilitates capital formation which leads to faster economic growth.

Nourzad (2002) analyzes the effect of financial development on productive efficiency using eight measures of financial development for countries at different stages of economic development. Nourzad analyzes three sets of panels of data: annual for twenty-nine countries from 1966-90, annual data for eighteen countries from 1970-90, and five year average data for twenty-eight countries from 1970-90. The author finds that productive efficiency is greater in countries that have more developed financial sectors.

King and Levine (1993) analyze the relationship between measures financial development and real GDP per capita growth, the rate of physical capital accumulation, and increases in efficiency over the period from 196089. K\&L uses four measures of financial development: financial depth (ratio of liquid liabilities to GDP), the level of banking, the ratio of credit issued to non-financial private firms to total credit, and the ratio of credit issued to private firms to GDP. The authors report that higher levels of financial development are positively associated with faster rates of economic growth and that the level of financial development is a good indicator of future growth prospects. ${ }^{14}$

Beck, Levine and Loayza (2000) analyze the relationship between financial development and economic growth, total factor productivity growth, physical capital accumulation and private savings rates. The authors report that there is a large positive effect of financial intermediaries and total factor productivity growth and economic growth but a lesser effect for long-term economic growth and total factor productivity growth.

Atje and Jovanovic (1993) find a large effect of stock markets on economic growth but no relationship for bank lending. A\&J analyze forty countries for 1990 for GDP per adult and growth in GDP per adult relative to investment as a percent of DP averaged from 1960 to 1985, the percent of the working age population in secondary school, the value of stock traded in the stock market relative to GDP, and claims on the private sector by the monetary authority, and bank deposits as a percent of GDP. Alternatively, Harris (1997) argues that the Atje and Jovanovic results are not supported by empirical results. Harris analyzes data for forty-nine countries over the period from 1980-91 for the growth in GDP per unit of effective labor, investment as a percent of GDP, the growth of total employed labor, and the total value of shares traded on the stock market as a percent of GDP. Harris reports that the level of stock market activity has little explanatory power in the developing country sample and weak explanatory power for the developed country sample.

Wurgler (2000) analyzes the relationship between financial markets and capital allocation in sixty-five countries from 1963-95. Wurgler finds that countries with more (less) developed financial markets shift capital to growing (declining) industries and away from declining (growing) industries. The efficiency of the financial system is inversely related to government ownership in the economy and directly related to information availability for firms and legal protections for minority stockholders.

\section{RESEARCH DESIGN}

Countries with higher levels of GNI have lower levels of poverty, World Development Indicators 2001. Increases in the growth rate of GNI can have a dramatic effect on economic growth and development, with China increasing GNI per capita sevenfold over the last forty years with a growth rate of six percent per year and with Malawi increasing GNI per capita by fifty percent with a growth rate of only one percent per year. Even though developing countries have higher savings rates that developed countries, the developing countries supply the bulk of worldwide savings. In 1999, total gross domestic savings worldwide was $\$ 30.9$ billion of which $\$ 24.3$ billion (79\%)

\footnotetext{
${ }^{14}$ Savvides (1995) finds that financial development contributes to economic growth in Africa.
} 
was provided by the high income economies. Even with high savings rates, developing countries cannot save enough capital to meet investment needs.

The World Bank, in "Estimation of Internationally Comparable Per Capita Income Numbers for Operational Purposes," categorizes countries by GNI per capita measured in United States dollars to determine lending terms to countries in a transparent fashion. Lower income countries receive better lending terms with respect to such items as grace and repayment periods, fees, and interest rates. The World Bank uses GNI per capita as a proxy for economic well being. In the technical notes to the World Bank Group - Data and Statistics, numerous measures of economic well being exist such as sanitation facilities, malnutrition, telephones, life expectancy, paved roads, stock market capitalization, literacy rate, and infant mortality rate, all of which variables are highly correlated with GNI per capita.

Countries are divided into four categories: low income economies, lower middle income economies, high middle income economies, and high income economies. Gross national income is a measure of the income created by the residents of a nation from both international and domestic activities. Gross domestic product measures the income generated in an economy by both residents and non-residents of an economy. GNI per capita is converted from domestic currency to dollars using the Atlas conversion method. The Atlas conversion factor is the arithmetic average of the current foreign exchange rate and the foreign exchange rate for the two previous years adjusted for the ratio of the domestic price level change and the dollar price level change.

The data used in this study are taken from the Standard and Poor's Emerging Markets Factbook 2004 and the International Finance Corporation Emerging Stock Markets Factbook for 1996. The sample size ranges from seventy-eight countries for 1994to 1002 countries for 1998. The average number of countries each year is ninetyfour. The input variables used are gross national income for 1994 to 2003, total stock market capitalization for 1994 to 2003, and gross national income per capita for 1994 to 2003. Market capitalization as a percent of gross national income is computed by the simple ratio of total stock market capitalization in each country divided by total gross national income for that country.

The hypothesis that is being tested is that the ratio of the value of the stock market capitalization as a proportion of GNI will be higher in more developed economies and lower in less developed economies. We test this hypothesis by measuring the correlation between the market capitalization as a proportion of gross national income ratio and gross national income per capita. We run linear regressions of the cross sectional data.

\section{EMPIRICAL RESULTS}

The summary results for each year for the four income groups - low income, low middle income, high middle income, and high income for the averages for each year from 1994-2003 are provided in Table 1. For 1994, the average ratio of market capitalization to GNI for high income economies is 0.67 and for low income economies is 0.19. For the high income market capitalization to GNI for high income economies rises to 1.09 by 2003 but decreases to 0.17 for low income economies. Market capitalization to GNI remains relatively constant for middle income economies. The natural logarithm of GNI per capita remains relatively constant for high income economies at about ten, for high middle income economies at 8.50, for low middle income economies at about 7.50, and for low income economies at about 6.00 .

Table 2 shows the regression results for each year of the ten year sample period: the $\mathrm{R}^{2}$, the adjusted $\mathrm{R}^{2}$, the $F$ ratio, the statistical significance of the $F$ ratio, the intercept and the $t$ statistic for the intercept and the regression coefficient, the t-statistic for the regression. The regression results are consistent for the ten-year sample period. The intercept is about 7.5 each year and is statistically significant at the one percent level. The beta coefficient is more variable ranging from 0.80 in 1994 to 3.26 in 1999 and is statistically significant in each year. The adjusted $R^{2}$ ranges from 0.08 in 1994 to 0.47 in 1999. 


\section{SUMMARY AND CONCLUSIONS}

The interaction between process of economic development and the level of development of the stock market are explored in this paper for the period from 1994 to 2003. There is substantial evidence that capital markets are a necessary part of the economic growth and development process. Developed economies have developed stock markets that reflect the ability of entrepreneurs to raise large sums of money and reflect the markets ability to direct funds to successful entrepreneurs. Low income economies do not have stock markets or have rudimentary stock markets that do not provide sources of funds to entrepreneurs or perform the function of capital allocation, efficiently. The empirical results of this paper demonstrate that over the period of study from 1994 to 2003, countries that have higher levels of income generally have higher levels of financial institutional development as reflected in the ratio of stock market capitalization to GNI.

A stock market provides the users of capital a means of acquiring large amounts of financial resources. In addition, a stock market provides a mechanism by which small savers can invest in the economic development of their country. Capital markets are the mechanism by which more productive firms acquire the funds necessary to continue growing and providing the increased productivity that leads to economic development that is reflected in higher gross national income per capita. As can be seen in the empirical results of this paper, high income economies have stock markets with relatively high market capitalization values.

As a matter of policy, governments that wish to promote long term economic growth and development should create a political and economic environment in which capital markets can flourish. In the absence of well developed capital markets, entrepreneurs are not able to raise the large sums of money needed to sustain growth. In addition, the allocation of capital function is not performed satisfactorily and long term economic growth and development does not happen. All developed economies have well developed stock markets while not low income economy has a well developed stock market.

\begin{tabular}{|c|c|c|c|c|c|c|c|c|c|c|}
\hline \multicolumn{11}{|c|}{$\begin{array}{c}\text { Table } 1 \\
\text { Market Capitalization to GNI and the Natural Logarithm of GNI per capita } \\
1994-2003\end{array}$} \\
\hline MKT/GNI & 1994 & 1995 & 1996 & 1997 & 1998 & 1999 & 2000 & 2001 & 2002 & 2003 \\
\hline HIE & 0.67 & 0.66 & 0.69 & 0.70 & 0.88 & 1.19 & 1.07 & 0.86 & 0.78 & 1.09 \\
\hline HMIE & 0.47 & 0.43 & 0.44 & 0.38 & 0.36 & 0.51 & 0.40 & 0.33 & 0.37 & 0.39 \\
\hline LMIE & 0.29 & 0.20 & 0.20 & 0.16 & 0.16 & 0.20 & 0.22 & 0.24 & 0.27 & 0.40 \\
\hline LIE & 0.19 & 0.14 & 0.14 & 0.13 & 0.11 & 0.16 & 0.12 & 0.15 & 0.25 & 0.17 \\
\hline LN(GNIPC) & 1994 & 1995 & 1996 & 1997 & 1998 & 1999 & 2000 & 2001 & 2002 & 2003 \\
\hline HIE & 9.96 & 9.97 & 10.01 & 9.99 & 9.98 & 12.10 & 1.07 & 9.93 & 9.91 & 10.07 \\
\hline HMIE & 8.33 & 8.44 & 8.41 & 8.40 & 8.45 & 9.40 & 0.40 & 8.46 & 8.45 & 8.44 \\
\hline LMIE & 7.20 & 7.43 & 7.40 & 7.40 & 7.33 & 7.69 & 0.22 & 7.39 & 7.36 & 7.42 \\
\hline LIE & 5.99 & 5.97 & 6.05 & 6.00 & 5.89 & 6.90 & 0.12 & 6.05 & 5.97 & 6.10 \\
\hline
\end{tabular}

\begin{tabular}{|c|c|c|c|c|c|c|c|c|c|c|}
\hline & & rket Ca & lizatio & $\begin{array}{r}\text { Reg } \\
\text { GNI aI }\end{array}$ & $\begin{array}{l}\text { able } 2 \\
\text { ion Re } \\
\text { he Natu } \\
4-2003\end{array}$ & Logari & of $\mathbf{G N}$ & r capita & & \\
\hline & 1994 & 1995 & 1996 & 1997 & 1998 & 1999 & 2000 & 2001 & 2002 & 2003 \\
\hline R2 & 0.09 & 0.16 & 0.17 & 0.32 & 0.40 & 0.48 & 0.38 & 0.34 & 0.22 & 0.27 \\
\hline Adj R2 & 0.08 & 0.15 & 0.16 & 0.31 & 0.39 & 0.47 & 0.37 & 0.34 & 0.21 & 0.26 \\
\hline $\mathbf{F}$ & 7.59 & 15.67 & 17.59 & 46.14 & 65.49 & 88.27 & 56.82 & 51.52 & 27.44 & 31.96 \\
\hline Sign & 0.01 & 0.00 & 0.00 & 0.00 & 0.00 & 0.00 & 0.00 & 0.00 & 0.00 & 0.00 \\
\hline Intercept & 7.86 & 7.83 & 7.85 & 7.56 & 7.44 & 7.42 & 7.47 & 7.42 & 7.57 & 7.71 \\
\hline t-stat & 37.90 & 42.47 & 44.96 & 48.65 & 50.28 & 25.36 & 46.98 & 46.82 & 44.37 & 46.12 \\
\hline Beta & 0.80 & 1.12 & 1.06 & 1.82 & 1.86 & 3.26 & 1.46 & 1.72 & 1.31 & 1.07 \\
\hline t stat & 2.75 & 3.96 & 0.25 & 6.79 & 8.09 & 9.39 & 7.54 & 7.18 & 5.24 & 5.65 \\
\hline
\end{tabular}




\section{BIBLIOGRAPHY}

1. Arrow, Kenneth. The Role of Securities in the Optimal Allocation of Risk Bearing, Review of Economic Studies, 1964, pp. 91-96.

2. Atje, Raymond and Boyan Jovanovic. Stock Markets and Development, European Economic Review, volume 37, 1993, pp. 632-640.

3. Bakaert, Geert, Campbell R. Harvey, and Robin L. Lumsdaine. Dating the Integration of World Equity Markets, Journal of Financial Economics, volume 65, 2002, pp. 203-247.

4. Beck, Thorsten, Ross Levine and Norman Loayza. Finance and the Sources of Growth, Journal of Financial Economics, volume 58, 2000, pp. 261-300.

5. Bernstein, William J., The Birth of Plenty, McGraw-Hill, New York, 2004.

6. Bernstein, William J. Of Markets, Economies, and Populations, Efficient Frontier, Summer 2002.

7. Demetriades, Panicos O. and Khaled A. Hussein. Does Financial Development Cause Economic Growth? Timeseries Evidence from 16 Countries, Journal of Development Economics, volume 51, 1996, pp. 387-411.

8. Demirguc-Kunt, Asli and Vojislav Kamsimovic. Law, Finance, and Firm Growth, Journal of Finance, volume LIII, number 6, December 1998, pp. 2107-2137.

9. Diamond, Jared. Guns, Germs, and Steel: The Fates of Human Societies, Random House, 1997.

10. Estimation of Internationally Comparable per capita income Numbers for Operational Purposes, World Bank, 2002.

11. Eugene Fama, Efficient Capital Markets: A Review of Theory and Empirical Work, Journal of Finance, May 1970, pp. 383-417

12. Harris, Richard D. F. Stock Markets and Development: A Re-Assessment, European Economic Review, volume 41, 1997, pp. 139-146.

13. Husten, Steven and Michael Melvin. International Economics, Fifth Edition, Addsion-Wesley, Boston, 2001.

14. King, Robert G. and Ross Levine. Finance and Growth: Schumpeter Might Be Right, Quarterly Journal of Economics, volume 108, August 1993, pp. 717-737.

15. Levine, Ross and Sara Zervos. Stock Markets, Banks, and Economic Growth, American Economic Review, volume 88, number 3, pp. 537-558.

16. Maddison, Angus. The World Economy: A Millennial Perspective, Development Centre of the Organization for Economic Co-Operation and Development, 2001.

17. Markowitz, Harry. Portfolio Selection, The Journal of Finance, March 1952, pp. 77-91.

18. Nourrzad, Farrokh. Financial Development and Productive Efficiency: A Panel Study of Developed and Developing Countries, Journal of Economics and Finance, volume 26, number 2, Summer 2002, pp. 138-149.

19. Porter, Michael E. The Competitive Advantage of Nations, The Free Press, New York, 1990.

20. Rajan, Raghuram G. and Luigi Zingales. Financial Dependence and Growth, American Economic Review, volume 88 , number 3, pp. 559-586.

21. Roll, Richard and John Talbott. Why Many Developing Countries Just Aren't? The Heritage Foundation, November 13, 2001.

22. Rostow, Walt Whitman. The Stages of Economic Development, Second Edition, Cambridge University Press, Cambridge, 1971.

23. Savvides, Andreas. Economic Growth in Africa, World Development, volume 23, number 3, pp. 449-458.

24. Schultz, Theodore. Investment in Human Capital, American Economic Review, March 1961.

25. Schumpeter, Joseph A. Theory of Economic Development, 1911.

26. Sharpe, William F. A Simplified Model for Portfolio Analysis, Management Science, January 1963, pp. $277-$ 293.

27. Sharpe, William F. Capital Asset Prices: A Theory of Market Equilibrium under Conditions of Risk, The Journal of Finance, September 1964, pp. 425-552.

28. Solow, Robert. A Contribution to the Theory of Economic Growth, Quarterly Journal of Economics, 70, Number 1, February 1956.

29. Standard and Poor's Emerging Stock Markets Factbook 2001, Standard and Poor's, New York, 2001.

30. James Tobin, Liquidity Preference as Behavior Towards Risk, The Review of Economic Studies, February 1958 , pp. 65-86.

31. World Bank Group - Data and Statistics, Technical Notes, 2002.

32. World Development Indicators, World Bank, 2001.

33. Wurgler, Jeffrey. Financial Markets and the Allocation of Capital, Journal of Financial Economics, volume 58, 2000, pp. 187-214. 